\title{
Debt Policy Analysis Through Profitability as Moderating Variables in Prop- erty \& Real Estate Companies That Go Public on the IDX
}

\author{
Erni Wijayanti, Tri Kartika Pertiwi* \\ Economic and Bussiness Faculty, Universitas Pembangunan Nasional “Veteran” Jawa Timur, Indonesia
}

*Corresponding author:

E-mail:

tri.pertiwi.mnj@upnjatim.ac.id

\begin{abstract}
This study is aimed at examining profitability in moderating the effect of dividend policy and business risk on debt policy by using the population of property \& real estate companies that go public on the IDX for the 2016-2018 period. Using purposive sampling to obtain a sample of 34 companies. Using moderated regression analysis with absolute difference testing as an analysis technique. So that the dividend policy results are obtained, business risk can contribute to debt policy, profitability can moderate the effect of dividend policy on debt policy, and profitability can moderate the effect of business risk on debt policy.
\end{abstract}

Keywords: Debt Policy, dividend policy, business risk, profitability

\section{Introduction}

The development of Indonesian property \& real estate companies requires companies to have more funds to improve performance competence, innovation, and product development to achieve company targets in increasing the welfare of stockholders by increasing company value and maximizing company profits. Sources of funding can be in the form of internal funds (retained earnings \& accumulated depreciation of assets) or external funds (debt, issuance of bonds and, shares). If the company decided to choose the source of funds using debt, the company must repay their loan at a specified time basis with the interest expense. The company would risk bankruptcy if they are unable to repay off all its debts.

Based on the results of financial reports throughout 2017, PT Bakrieland Development Tbk stated that there was no dividend distribution because the company suffered a loss of Rp. 271.53 billion in 2017 and Rp. 548.1 billion in 2016. The loss originated from the amount of debt the company had, which resulted in interest. banks amounting to Rp. 33 billion in 2017 \& Rp. 59 billion in 2016. PT Lippo Karawaci Tbk has divested its assets of Rp. 2.2 trillion in November 2020. This is done by the company to fulfill all debt repayment obligations and stabilize the liquidity position of the company.

The phenomenon of a company experiencing financial difficulties in paying debts has resulted in the company having to divest its assets. Bankruptcy or bankruptcy will be experienced by companies if they often experience financial difficulties to pay off the debts they have. Therefore, a good debt policy management can prevent the company from having trouble paying debts, so that the company will avoid bankruptcy cases and investors will invest their capital in the company (Andari, 2009).

According to the research results of Parada et al. (2013), business risk cannot contribute to debt policy. However, the results of research by Murtiningtyas (2012) state that dividend policy

\section{How to cite:}

Wijayanti, E., \& Pertiwi, T. K. (2021). Debt policy analysis through profitability as moderating variables in property \& real estate companies that go public on the IDX. $5^{\text {th }}$ International Seminar of Research Month 2020. NST Proceedings. 
cannot contribute to debt policy, but profitability \& business risk can contribute in a negative direction to debt policy. This is not by Sheisarvian et al., (2015) who say that dividend policy can contribute negatively to debt policy.

Based on the explanation above, both through phenomena and research on previous research gaps, researchers are interested in examining whether dividend policy and business risk can contribute to debt policy through profitability as a moderating variable.

\section{Material and Methods}

This research uses quantitative methods with moderation regression analysis techniques. Using the dependent variable debt policy (Y). Using the independent variable dividend policy (X1) \& business risk (X2). The moderating variable is profitability (Z). The test carried out is the classical assumption test. Hypothesis testing utilizing partial testing, simultaneous testing, and testing the coefficient of determination.

Using the population of Property \& Real Estate companies listed on the IDX, a total of 81 companies with a purposive sampling technique. The criteria used are 1) Listed on the IDX 2016-2018, 2) Publishing financial reports and distributing dividends for 2016-2018. With these criteria, samples were obtained by 34 companies. The data source used is the Financial Statements for the period 2016 to 2018 which were obtained from www.idx.co.id.

Table 1. Variable measurement

\begin{tabular}{ccc}
\hline No & Variable & Measurement \\
\hline 1. & Debt Policy (DER) & DER= Total Debt/ total equity \\
2. & Dividend Policy (DPR) & DPR= Dividend per Share/profit per share \\
3. & Business Risk & Bisniss Risk $=\delta$ (EBIT/total assets) \\
4. & Profitability (ROE) & ROE $=$ Net Profit $/$ Total Equity \\
\hline
\end{tabular}

\section{Results and Discussion}

Classical assumption test results

Normality test

Using the Kolmogorov-Smirnov test at a significance value of 5\%. The test results prove the probability value of all variables in the model $>0.05$. So that it can be concluded that the data has a normal distribution.

\section{Multicollinearity test}

The test results produce the VIF calculation results for all independent variables less than 10.00 and the tolerance value for all independent variables is more than 0.10 , so it can be concluded that there is no multicollinearity between each independent variable and other independent variables.

\section{Heteroscedasticity test}

Using the Spearman Rank Correlation test with a significance of 0.05 . The test results show that the significance value of all independent variables is more than $5 \%$, so it can be concluded that the residual and independent variables in the regression model do not have a significant correlation. 


\section{Autocorrelation test}

Yields a DW 1.668 test. The results of these calculations are 5\% significance compared to the value of the DW table, $\sum$ data $(\mathrm{N})=83$ and $\sum$ the independent variable $(\mathrm{K})=5$ and $\alpha=0.05$ are $\mathrm{dL}$ $=1.5183$ and $\mathrm{dU}=1.7728$ and the value of $4-\mathrm{dU}=4-1.7728=2.2272$. This means that $\mathrm{dL}<\mathrm{dW}$ $<\mathrm{dL}$, then it can be concluded that there is no autocorrelation.

Hypothesis test results

- Partial test (t-test)

Aims to show the impact of independent variables individually to explain the dependent variable with a significance of 0.05 .

Table 2. Hypothesis results

\begin{tabular}{lllll}
\hline \multicolumn{1}{c}{ Variable } & \multicolumn{1}{c}{ B } & & t & Sig \\
\hline Debt Policy (X1) & .820 & 2.191 & .031 & \\
Business Risk(X2) & -380.579 & -3.324 & .001 & \\
Profitability(Z) & 4.123 & 2.687 & .009 & \\
X1.Z & 8.305 & 2.935 & .004 & \\
X2.Z & -1740.639 & -2.430 & .017 & \\
\hline
\end{tabular}

source: processed data

According to the results of hypothesis testing, it is concluded that 1) Dividend Policy (X1) can make a positive contribution to Debt Policy (Y) with a coefficient of 0.820 \& a significance level of $0.031<0.05 .2$ ) Business Risk (X2) can contribute negatively to Debt Policy (Y) with a coefficient of -380.579 and a significance level of $0.001<0.05$. 3) Profitability moderates Dividend Policy (X1 ${ }^{*} \mathrm{Z}$ ) has a significant positive effect on Debt Policy (Y) with a coefficient of 8.305 and a significant value of $0.004<0.05 .4$ ) Profitability moderates Business Risk (X2 * Z) has a significant negative effect on Debt Policy (Y) with a coefficient of 1740.639 and a significant level of $0.017<0.05$.

- Simultaneous test (Test F)

Based on the ANOVA test obtained F - count 6.468 through a significance level of 0.000 . So, it can be concluded that the independent variables jointly affect the level of debt policy.

- Determination coefficient test

The test results show Determination Coefficient $(R 2)=0.296$, so the variables of Dividend Policy (X1), Business Risk (X2), Profitability Moderated Dividend Policy (X1 * Z), and Business Risk moderated Profitability (X2* Z) are able to explain the variable Debt Policy (Y) as much as $29.6 \%$, and the remaining $70.4 \%$ is explained by other variables besides the independent variables in the model.

- $\quad$ Effect of dividend policy (X1) on debt policy (Y)

A dividend policy is a strategy to determine how much profit to be given to stockholders. The direction of the positive relationship between dividend policy and debt policy means that if the company's dividends are high, the debt will also be high. This research supports the trade-off theory which states that companies with high profits will have a high dividend distribution rate (Umbarwati \& Fachrurrozie, 2018). Therefore, if the company increases the amount of its dividend distribution, it will decrease the internal funds provided for operational activities. So that the company will go into debt to meet the operational needs of the company. So, it can be said that the high dividends distributed to stockholders will also cause a decrease in debt owed by the company. 
- $\quad$ Effect of business risk (X2) on debt policy (Y)

Business risk is a condition or factor which can cause a loss or negative impact on operational activities or even on the company's profitability. The negative relationship of business risk in debt policy means that if the business risk in the company is high, the debt will below. This research is comparable to the pecking order theory which states that in funding activities, companies will prioritize internal funds rather than external funds (Hardiningsih \& Oktaviani, 2012). Thus, the high business risk makes companies tend to prioritize funding from retained earnings and stay away from funding through debt to minimize the risk that the company will get. Therefore, it can be concluded that the high the business risk, the smaller the level of debt the company has. Meanwhile, the low level of business risk leads to higher debt.

- Effect of dividend policy (X1) on debt policy (Y) through profitability (Z) as a moderating variable.

Profitability reflects how much net profit a company can generate when carrying out its operational activities by comparing the amount of net profit with total equity. If the value of profitability is large, the company's operational activities are carried out well. The results of the research carried out are comparable to agency theory which states that companies with high profitability tend to share the benefits they have in the form of dividends to minimize manager disputes with stockholders (Prathiwi \& Yadnya, 2017). And according to the trade-off theory which says high profitability, the company has high debt too. This is because the company distributes its profitability in the form of dividends which will cause the company's internal funds to decrease. Therefore, the company will go into debt to fulfill its operational activities. So, it can be said that Profitability can moderate (strengthen) the Dividend Policy against the Debt Policy.

- Effect of business risk (X2) on debt policy (Y) with profitability as a moderating variable (Z)

The level of success of the company in managing its business can be seen from how much profit it generates. The better the company's financial performance, the more the company value will increase which will increase profitability (Pertiwi \& Pratama, 2012). Profitability contributes to the company's business risk on debt policy. The high business risk of a company results from a low level of profitability. Therefore, the company will reduce debt and even tend to avoid debt because the company wants to avoid the risk of inability to pay off debt and interest. Conversely, the low level of business risk the company has is the result of the high level of profitability. Therefore, the debt owed by the company will increase because the company captures the low level of business risk as an opportunity to increase the company's growth. So, it can be concluded that Profitability can moderate (weaken) the relationship between Business Risk and Debt Policy.

\section{Conclusion}

According to the results of the analysis, it can be seen that the dividend policy variable can contribute in the same direction as the debt policy, the business risk variable can contribute to the opposite direction of the debt policy, the profitability variable can contribute, namely strengthening the relationship between dividend policy on debt policy, and The profitability variable can contribute, namely weakening the relationship between business risk and the debt policy of property \& real estate companies on the IDX for the 2016-2018 period.

This study still has limitations, namely the low coefficient of determination where other variables outside the regression model of this study influence debt policy. Therefore, it is suggested for further researchers to add variables that have more influence on debt policy outside of this research variable. 


\section{References}

Andari, R. (2009). Manajemen keuangan suatu pengantar. Bandung: UPI Press.

Bakrieland Digugat Pailit Gara-gara Utang Anak Usaha Rp 1,5 Triliun. (2013). Detik.Com. https://finance.detik.com/bursa-danvalas/d-2354225/bakrieland-digugat-pailit-gara-gara-utang-anak-usaha-rp-15-triliun

Hardiningsih, P., \& Oktaviani, R. M. (2012). Determinan kebijakan hutang (dalam agency theory dan pecking order theory). Dinamika Akuntansi Keuangan Dan Perbankan, 1(1), 118-125.

https://www.idx.co.id. Diakses 25 November 2019

Murtiningtyas, A. I. (2012). Kebijakan deviden, kepemilikan manajerial, kepemilikan institusional, profitabilitas, resiko bisnis terhadap kebijakan hutang. Accounting Analysis Journal, 1(2), 110-118.

Pertiwi, T. K., \& Pratama, F. M. I. (2012). Pengaruh Kinerja Keuangan Good Corporate Governance Terhadap Nilai Perusahaan Food and Beverage. Jurnal Manajemen Dan Kewirausahaan (Journal of Management and Entrepreneurship), 14(2), 118-127.

Pradana, H. R., Fachrurrozie, F., \& Kiswanto, K. (2013). Pengaruh Risiko Bisnis, Struktur Aset, Ukuran Dan Pertumbuhan Penjualan Terhadap Struktur Modal. Accounting Analysis Journal, 2(4), 118-124.

Prathiwi, D. I., \& Yadnya, I. P. (2017). Pengaruh free cash flow, struktur aset, risiko bisnis dan profitabilitas terhadap kebijakan hutang. E-Jurnal Manajemen, 6(1), 60-86.

Sheisarvian, R. M., Sudjana, N., \& Saifi, M. (2015). Pengaruh Kepemilikan Manajerial, Kebijakan Dividen dan Profitabilitas Terhadap Kebijakan Hutang (Studi pada Perusahaan Manufaktur yang Tercatat di BEI Periode 2010-2012). Jurnal Administrasi Bisnis, 22(1), 198-204.

Umbarwati, U. M. I., \& Fachrurrozie, F. (2018). Profitability as the moderator of the effects of dividend policy, firm size, and asset structure on debt policy. Accounting Analysis Journal, 7(3), 192-199. 